\title{
Amniotic Fluid C-peptide in Normal and Insulin-dependent Diabetic Pregnancies
}

\author{
G. Tchobroutsky ${ }^{1}$, I. Heard ${ }^{2}$, C. Tchobroutsky ${ }^{2}$, and E. Eschwege ${ }^{3}$ \\ ${ }^{1}$ Université Pierre et Marie Curie, Service de Diabétologie, Hôtel-Dieu Hospital, ${ }^{2}$ Maternité de Port-Royal, Paris, \\ and ${ }^{3}$ Unité de Recherche Statistique, Villejuif, France
}

\begin{abstract}
Summary. Glucose, insulin and C-peptide were determined in amniotic fluid from 28 normal and 46 insulin-treated diabetic pregnant women. Glucose, insulin and C-peptide concentrations in amniotic fluid were higher in the diabetics than in the normal subjects. In diabetic women insulin levels did not correlate with birth weight or birth weight adjusted for gestational age, but C-peptide did. C-peptide correlated poorly with insulin $(\mathrm{p}<0.05)$ in diabetics but closely $(p<0.002)$ in normal subjects. These results suggest that amniotic fluid investigations in insulintreated diabetic women should use C-peptide assays as these seem to reflect more closely the insulin production of the fetus than do insulin assays. There were no differences in amniotic fluid glucose, insulin and C-peptide concentrations where the amniotic fluid lecithin-sphingomyelin ratio indicated fetal pulmonary maturity or immaturity.
\end{abstract}

Key words: Amniotic fluid, C-peptide, insulin, diabetes, pregnancy.

Determination of amniotic fluid insulin concentration has been suggested as a good prognostic indicator of the status of the fetus and of the newborn in insulin-dependent diabetic pregnancies $[1,2]$. The fetal origin of insulin has been widely accepted [3] and it is presumed that this insulin is excreted in fetal urine. The transplacental transfer of insulin-binding antibodies generated in the mother in response to the administration of insulin might cast some doubt on the significance of amniotic fluid insulin concentrations, since circulating fetal insulin may be bound by these antibodies [4].

Recently plasma C-peptide measurements (the proinsulin connecting peptide which is secreted from the pancreatic beta cell in equimolar concentration with insulin), have provided a means to assess islet secretion despite the presence of circulating insulin antibodies [5]. Such an assay has been used to study infants of diabetic mothers, $[6,7]$ but not to study amniotic fluid until recently [8].

The aim of this study was to analyse the possible relationship between amniotic fluid concentrations of glucose, insulin and C-peptide and certain clinical variables in normal and insulin-dependent diabetic pregnant women.

\section{Materials and Methods}

\section{Patient Selection}

Sixty-one amniotic fluid samples were obtained by amniocentesis in 46 insulin-dependent diabetic subjects, and 32 samples from 28 pregnancies which subsequently proved to be normal.

Amniocenteses were performed on non-fasting patients between $1100 \mathrm{~h}$ and noon to determine fetal pulmonary maturity before elective Caesarean section, or in women with incomplete anti-D antibodies. In the latter case data were only used if the infant was found to be Rh-negative. A volume of $5-15 \mathrm{ml}$ was withdrawn. Cases with polyhydramnios and/or fetal malformation were excluded from both groups. Gestational age was confirmed by neurological examination of the newborn [9]. The diabetic patients were younger than the non-diabetic ones (mean SEM 25.3 years, range $17-37$, vs. 27.7 years, range $19-35$ ). The mean duration of their insulin therapy was 7.5 years (range 1-29). Their daily insulin dosage was $71 \mu \mathrm{U} / \mathrm{ml}$ (range 22-148). All patients had been treated by beef and pork insulins, before or during the pregnancy. Antibodies against insulin were not determined in maternal plasma.

\section{Amniotic Fluid Glucose, Insulin and C-peptide Determinations}

The amniotic fluid samples were centrifuged and frozen immediately at $-18^{\circ}$ until use. Glucose determinations were by an enzymatic procedure using the Beckman glucose analyser. 
Table 1. Amniotic fluid concentrations of glucose, insulin and Cpeptide related to gestational age

\begin{tabular}{|c|c|c|c|}
\hline Duration of pregnancy (weeks) & $<32$ & 32 to 35 & $\geqslant 36$ \\
\hline \multicolumn{4}{|l|}{ Glucose $(\mathrm{mg} / 100 \mathrm{ml})$} \\
\hline Normal & $\begin{array}{l}30 \\
(1)\end{array}$ & $\begin{array}{l}24 \pm 2 \\
(10)\end{array}$ & $\begin{array}{l}22 \pm 4 \\
(13)\end{array}$ \\
\hline Diabetics & $\begin{array}{l}- \\
(0) \\
-\end{array}$ & $\begin{array}{l}53 \pm 6 \\
(18) \\
p<0.01\end{array}$ & $\begin{array}{l}42 \pm 6 \\
(27) \\
p<0.05\end{array}$ \\
\hline \multicolumn{4}{|l|}{ Insulin $(\mu \mathrm{U} / \mathrm{ml})$} \\
\hline Normal & $\begin{array}{l}2 \\
(1)\end{array}$ & $\frac{6 \pm 1}{(11)}$ & $\begin{array}{c}7 \pm 1 \\
(15)\end{array}$ \\
\hline Diabetics & $(0)$ & $\begin{array}{l}15 \pm 2 \\
(17) \\
p<0.01\end{array}$ & $\begin{array}{l}25 \pm 7 \\
(27) \\
p<0.01\end{array}$ \\
\hline \multicolumn{4}{|l|}{ C-peptide $(\mathrm{ng} / \mathrm{ml})$} \\
\hline Normal & $\begin{array}{l}1.6 \\
(1)\end{array}$ & $\begin{array}{l}1.4 \pm 0.3 \\
(10)\end{array}$ & $\begin{array}{l}1.3 \pm 0.2 \\
(14)\end{array}$ \\
\hline Diabetics & $\begin{array}{l}- \\
(0) \\
-\end{array}$ & $\begin{array}{l}2.5 \pm 0.3 \\
(15) \\
p<0.05\end{array}$ & $\begin{array}{l}2.3 \pm 0.4 \\
(21) \\
p<0.06\end{array}$ \\
\hline
\end{tabular}

Number of subjects shown in parentheses. Results given as mean \pm SEM

Table 2. Relationships between amniotic fluid concentrations of glucose, insulin and C-peptide. Allowance was made for the effects of gestational age when calculating correlation coefficients

\begin{tabular}{llcc}
\hline & & Normal subjects & Diabetics \\
\hline Insulin & $\mathrm{r}$ & $0.64(24)$ & $0.39(34)$ \\
vs C-peptide & $\mathrm{p}$ & $<0.002$ & $<0.05$ \\
Insulin & $\mathrm{r}$ & $0.51(24)$ & $0.47(44)$ \\
vs glucose & $\mathrm{p}$ & $<0.05$ & $<0.01$ \\
Glucose & $\mathrm{r}$ & $0.53(22)$ & $0.50(35)$ \\
vs C-peptide & $\mathrm{p}$ & $<0.05$ & $<0.01$ \\
\hline
\end{tabular}

Number of subjects shown in parentheses. $\mathbf{r}$, correlation coefficient; $p$, significance level

Radioimmunoassay of insulin was performed according to Yalow and Berson with slight modifications using talc for separation of free and bound insulin [10]. All amniotic fluid samples were also incubated for 5 days at $4^{\circ}$ with $0.03 \mathrm{ng} / \mathrm{ml}$ of iodinated human insulin (specific activity $240 \mu \mathrm{Ci} / \mu \mathrm{g}, \mathrm{CEA}$ Saclay $\mathrm{n}^{\circ} 73045$.A.) in order to detect insulin antibodies according to Rosselin and associates [11] with slight modifications. C-peptide was measured using the Daiichi radioimmunoassay kit [12] (Guerbet Test - France Radioisotope Laboratoires, Tokyo). According to the supplier, cross-reaction with human proinsulin is 7 per cent on a molar basis. All the assays were run together, with various controls including known samples with low and high values. The sensitivity for C-peptide in our hands was $0.15 \mathrm{ng} / \mathrm{ml}$.

\section{Lecithin-Sphingomyelin ( $L / S)$ Ratio}

$\mathrm{L} / \mathrm{S}$ ratio was determined after centrifugation by the original technique of Gluck and associates [13], including acetone precipitation. The results were evaluated by visually comparing the rela- tive size and colour of the lecithin and sphingomyelin spots following thin-layer chromatography. In our laboratory a value of 2 or more is a reliable index of fetal maturity [14].

\section{Statistical Analysis}

In patients with repeated amniocentesis, only one sample was used for statistical analysis. The value selected corresponded to that which was less frequently represented at a given gestational age in order to improve the representativity of our population. Owing to the small number of subjects and the unequal variances of distribution, non-parametric tests for comparing means (Wilcoxon's test), and determining correlation coefficients (Spearman's test) were used. In order to take into account the differences in gestational age between the groups under comparison, covariance analysis and partial correlations were used.

\section{Results}

Insulin-binding antibodies were detected in only one amniotic fluid sample obtained in a diabetic pregnancy. This sample was discarded.

Amniotic fluid glucose, insulin and C-peptide concentrations were higher in the insulin-treated diabetics than in the controls, although the difference barely reached the significant level for C-peptide (Table 1).

The interrelationships between amniotic fluid concentrations of glucose and insulin and C-peptide are given in Table 2 . The main feature is the higher correlation coefficient between insulin and C-peptide in normal subjects $(\mathrm{r}=0.64, \mathrm{p}<0.002)$ than in diabetics $(r=0.39, p<0.05)$.

In order to study the relationship to birth weight, only samples obtained in the week before delivery were analysed. Two variables were studied, namely actual birth weight, and the percentile from the weight chart of Lubchenco. In normal pregnancies there was no significant correlation between these two variables and amniotic fluid glucose, insulin or C-peptide. In insulin-treated diabetic pregnancies, no significant correlation was found between actual birth weight, percentile of Lubchenco's chart and amniotic fluid glucose or insulin. In contrast, C-peptide correlated positively with actual birth weight $(p<0.01)$, and with the percentile of the weight chart of Lubchenco $(p<0.05)$.

No relationship was observed with an immature $(<2)$ or mature $(\geqslant 2) \mathrm{L} / \mathrm{S}$ ratio for any of the variables studied (Table 3 ).

\section{Discussion}

In this study amniotic fluid insulin concentrations correlated poorly with amniotic fluid C-peptide in the diabetics $(r=0.39)$ in contrast to the close corre- 
Table 3. Glucose, insulin and C-peptide concentrations in amniotic fluid according to the presence of a mature or an immature lecithinsphingomyelin ratio $(\mathrm{L} / \mathrm{S})$

\begin{tabular}{|c|c|c|c|c|c|c|}
\hline & \multicolumn{3}{|c|}{ Normal subjects } & \multicolumn{3}{|l|}{ Diabetics } \\
\hline & $\overline{\mathrm{L} / \mathrm{S}<2}$ & $\mathrm{~L} / \mathrm{S} \geqslant 2$ & $\mathrm{p}$ & $\mathrm{L} / \mathrm{S}<2$ & $\mathrm{~L} / \mathrm{S} \geqslant 2$ & $\mathrm{p}$ \\
\hline $\begin{array}{l}\text { Weeks of } \\
\text { pregnancy }\end{array}$ & $\begin{array}{l}35 \pm 0.6 \\
(15)\end{array}$ & $\begin{array}{l}37 \pm 0.5 \\
(12)\end{array}$ & $<0.06$ & $\begin{array}{l}35 \pm 1 \\
(20)\end{array}$ & $\begin{array}{l}36 \pm 1 \\
(24)\end{array}$ & $<0.01$ \\
\hline $\begin{array}{l}\text { Insulin } \\
\mu \mathrm{U} / \mathrm{ml}\end{array}$ & $\begin{array}{l}7.5 \pm 1 \\
(15)\end{array}$ & $\begin{array}{l}5 \pm 1 \\
(12)\end{array}$ & NS & $\begin{array}{l}14 \pm 2 \\
(20)\end{array}$ & $\begin{array}{l}27 \pm 8 \\
(24)\end{array}$ & NS \\
\hline $\begin{array}{l}\text { C-peptide } \\
\mathrm{ng} / \mathrm{ml}\end{array}$ & $\begin{array}{l}1.5 \pm 0.2 \\
(14)\end{array}$ & $\begin{array}{l}1.2 \pm 0.3 \\
(11)\end{array}$ & NS & $\begin{array}{l}2.2 \pm 0.3 \\
(18)\end{array}$ & $\begin{array}{l}2.5 \pm 0.5 \\
(1.8)\end{array}$ & NS \\
\hline $\begin{array}{l}\text { Glucose } \\
\mathrm{mg} / 100 \mathrm{ml}\end{array}$ & $\begin{array}{l}26 \pm 3 \\
(13)\end{array}$ & $\begin{array}{l}20 \pm 3 \\
(11)\end{array}$ & NS & $\begin{array}{l}52 \pm 6 \\
(21)\end{array}$ & $\begin{array}{l}42 \pm 6 \\
(24)\end{array}$ & NS \\
\hline
\end{tabular}

Number of subjects shown in parentheses. Results given as mean \pm SEM. p, significance level; NS, not significant

lation found in the normal subjects $(\mathrm{r}=0.64)$ (Table 2). Moreover, amniotic fluid insulin concentrations in diabetics did not correlate with birth weight, or the percentile of the Lubchenco's weight chart, but amniotic fluid C-peptide did. These results suggest that in insulin-treated diabetics C-peptide concentration in amniotic fluid may reflect more accurately fetal insulin production than amniotic fluid insulin concentration.

These results are not surprising since circulating fetal insulin may be affected by insulin antibodies transferred from the insulin-treated mother through the placenta. Even if insulin antibodies seldom reach amniotic fluid ( 1 out of 46 in our study), this does not mean that interference between fetal insulin and insulin antibodies does not occur inside the fetus.

Studies in man have shown that urinary C-peptide is a valuable index of insulin secretion and provides a good assessment of B-cell function [15]. Cpeptide does not cross-react with insulin antibodies. A variable cross-reactivity with endogenous proinsulin has been described but only small quantities of proinsulin are excreted in the urine, even in patients whose serum contains substantial amounts of endogenous pro-insulin [16]. Moreover it has also been shown that C-peptide is excreted at a higher rate than insulin in the urine of rats, and that the kidney represents the major site for the clearance of C-peptide in this species while both the kidney and the liver play important roles in the clearance of insulin [17]. It could be suggested that amniotic fluid Cpeptide is the result of $\mathrm{C}$-peptide excretion via the fetal urine, which contributes to amniotic fluid.

Our results cast some doubt on previous studies on amniotic fluid insulin from diabetic-treated women. Spellacy et al. did not assay amniotic fluid samples for insulin in insulin-treated pregnancies for the aforementioned reasons [4]. These authors found a relationship between amniotic fluid insulin levels and birth weight in normal pregnancies. We were not able to find such a relationship probably because the number of amniotic fluid samples in the normal group, in the last week before delivery, was too small, 8 versus 38 in Spellacy's series.

No significant relationship between the lecithinsphingomyelin ratio and amniotic fluid glucose, insulin or C-peptide concentrations was observed in our study. It has been suggested that high insulin levels may inhibit pulmonary surfactant synthesis and be responsible for the high incidence of respiratory distress syndrome in infants of diabetic mothers [18]. Our results are not in agreement with such a hypothesis, whether in normal subjects or in diabetics, in contrast to the report by Draisey et al. [19].

In conclusion, amniotic fluid insulin and C-peptide concentrations correlate closely in non-insulin treated diabetic women. Either of these assays may be performed in these patients. Commercial kits for insulin assays are cheaper than those for C-peptide, and may be preferred. But in insulin-treated women, amniotic fluid $\mathrm{C}$-peptide radioimmunoassay is more reliable than insulin radioimmunoassay.

Acknowledgements. We gratefully acknowledge the help of N. Thibult for statistical analysis, and of G. Breart. Supported by grant INSERM 567888.

\section{References}

1. Newman RL, Tutera F, Tutera G (1976) The glucose-insulin ratio in amniotic fluid. Obstet Gynecol 47: 599-601

2. Weiss PAM, Lichtenegger W, Winter R, Pürstner P (1978) Insulin levels in amniotic fluid. Management of pregnancy in diabetes. Obstet Gynecol 51: 393-398

3. Casper D I, Benjamin F (1970) Immunoreactive insulin in amniotic fluid. Obstet Gynecol 35: 389-393

4. Spellacy WN, Buhi W C, Bradley B, Kolsinger KK (1973) Maternal, fetal and amniotic fluid levels of glucose, insulin and growth hormone. Obstet Gynecol 41: 323-331 
5. Block M B, Mako ME, Steiner D F, Rubenstein AH (1972) Circulating C-peptide immunoreactivity. Studies in normals and diabetic patients. Diabetes 21: 1013-1026

6. Block MB, Pildes RS, Mossabhoy NA, Steiner DF, Rubenstein AH (1974) C-peptide immunoreactivity (CPR): a new method for studying infants of insulin-treated diabetic mothers. Pediatrics 53: 923-928

7. Phelps R L, Freinkel N, Rubenstein A H, Kuzuya H, Metzger BE, Boehm JJ, Molsted Pedersen L (1978) Carbohydrate metabolism in pregnancy-15- Plasma C-peptide during intravenous glucose tolerance in neonate from normal and insulin-treated diabetic mothers. J Clin Endocrinol Metab 46: $61-68$

8. Andreani D, Fallucea F, Russo A, Maldonato A, Caccamo C, Lamalfa G, De Gado F, Pachi A (1979) Insuline, peptide Cet glucagon dans le liquide amniotique chez des femmes enceintes normales et diabétiques. In: Journées de Diabétologie de 1'Hôtel-Dieu. Flammarion Med. Sciences, Paris, p 93-101

9. Amiel-Tison C (1974) Neurologic evaluation of the small neonate: the importance of head straightening reactions. In: Gluck L (ed) Modern perinatal medicine. Year Book Medical Pub., Chicago, p 347-357

10. Rosselin G, Assan R, Yalow R S, Berson SA (1966) Separation of antibody-bound and unbound peptide hormones labeled with iodine I-131 by talcum powder and precipitated silica. Nature 212: $355-357$

11. Rosselin G, Tchobroutsky G, Assan R, Lellouch J, Dolais J, Derot M (1965) Etude quantitative d'anticorps humains antiinsulines animales par la methode radio-immunologique de Berson et Yalow. Comportement des anti-serums vis à vis d'insulines bovine, porcine et humaine. Diabetologia 1: 33-38

12. Kuzuya T, Matsuda A, Saito T, Yoshida S (1976) Human Cpeptide immunoreactivity (CPR) in blood and urine-evaluation of a radioimmunoassay method and its clinical applications. Diabetologia 12: 511-518
13. Gluck L, Kulovich MV, Borer RC Jr, Brenner PH, Anderson GG, Spellacy W N (1971) Diagnosis of the respiratory distress syndrome by amniocentesis. Am J Obstet Gynecol 109: $440-445$

14. Tchobroutsky C, Amiel-Tison C, Cedard L, Eschwege E, Rouvillois JL, Tchobroutsky G (1978) Lecithin-sphingomyelin ratio in 132 insulin-dependent diabetic pregnancies. Am J Obstet Gynecol 130: 754-760

15. Kuzuya T, Matsuda A, Sakamoto Y, Tanabshi S, Kajinuma H (1978) C-peptide immunoreactivity (CPR) in urine. Diabetes 27 [Suppl 1]: 210-215

16. Constan L, Mako M, Juhn D, Rubenstein AH (1975) The excretion of proinsulin and insulin in urine. Diabetologia 11 : $119-123$

17. Katz AI, Rubenstein AH (1973) Metabolism of proinsulin, insulin and C-peptide in the rat. J Clin Invest 52: 1113-1121

18. Smith B T, Giroud C J P, Robert M, Avery M E (1975) Insulin antagonism of cortisol-action of lecithin synthesis by cultured fetal lung cells. J Pediatr 87: 953-956

19. Draisey TF, Gagneja GL, Thibert R J (1977) Pulmonary surfactant and amniotic fluid insulin. Obstet Gynecol 50: 197-199

Received: June 13, 1979,

and in revised form: October 22, 1979

G. Tchobroutsky, M. D.

Université Pierre et Marie Curie

Hôtel-Dieu Hospital

Service de Diabétologie

1 Place du Parvis Notre-Dame

F-75181 Paris Cedex 04

France 